\title{
ANTIFUNGAL ACTIVITY OF ESSENTIAL OILS OF LEAVES, RHIZOMES OILS AND FRACTION WILD GINGER Elettariopsis slahmong CK Lim INHIBIT THE COLONY GROWTH OF Sclerotium rolfsii
}

\author{
Nurmansyah*,1, Herwita Idris ${ }^{1}$, Nasril Nasir ${ }^{2}$ \\ ${ }^{1}$ Research Instalation of Bogor Research Institute for Spice and Medicinal Plants, Laing Solok, Indonesia \\ ${ }^{2}$ Biology Departement, Faculty of Mathematics and Natural Sciences, Andalas University, Padang, \\ Indonesia \\ *Corresponding author \\ Email: nurmansyah70@yahoo.com
}

\begin{abstract}
This study aims to see the effectiveness of essential oils of leaves, rhizomes and fraction of wild ginger Ellettariopsis slahmong CK Lim against the pathogenic fungus Sclerotium rolfsii which causes rot disease of the stem base of peanut plants an in vitro.The study consisted of two sub activities: (a) inhibited of colony diameter using Patato Dextrosa Agar (PDA) medium and (b) inhibited of colony biomass using Potato dextrose Broth (PDB) medium, the treatments tested were leaf essential oil and rhizome of wild ginger and fractions A1, B2, C3 and D4, with concentration levels (0,100, 250 and 500 ppm). Experiments (a) and (b) were arranged in the form of a Completely Randomized Design (CRD) in factorial each with 4 replications. The results showed that the leaf essential oil and rhizome of wild ginger and its fractions had the potential to be used as a vegetable fungicide. The A1 fraction has the best antifungal effectiveness compared to the B2 fraction, leaf oil, rhizomes and other fractions, with the highest inhibition of diameter and biomass of $S$ rolfsii colony the $49.47 \%$ and $51.46 \%$. Essential oils of leaves and rhizome oil are not statistically significantly different, but in numerically leaf oil are better than rhizome oil. The C3 fraction showed the lowest colony diameter inhibition and biomass of $34.70 \%$ and $36.95 \%$. The best concentration level in inhibition the growth of $S$ rolfsii mushroom is 500 ppm, with inhibition of the diameter and biomass of the colony by $81.74 \%$ and $84.25 \%$.
\end{abstract}

Keywords: essential oil; rhizomes; fraction; wild ginger; sclerotum rolfsii

\section{Introduction}

Wild Ginger Elettariopsis slahmong C.K. Lim, is a wild plant of the family zinggiberaceae which was first discovered in Thailand by CK Lim this plant, it has a very strong pungent odor called the smelly leavis or stink bug plant (Picheansoonth \& Yupparach, 2007). There are several other species of the genus Elettariopsis that have been studied are E elan C.K. Lim, E exserta (Scort) Bak, E smithiae Y. K. Kam, E triloba (Gagneb) Loes, E manophylla and E wandokthong which are new species from Thailand (Picheansoonthon \& Yupparach, 2010). Wild Ginger contains essential oils from leaves, rhizomes and roots obtained by hydro destilation (Wong et al, 2006). This wild ginger plant is widely used as a spice and salad in Malaysia, Thailand and Indonesia (Magdaulih \& Nasir, 2014).

These wild ginger plants can also be found in West Sumatra as wild plants in the forest of Bonjol Pasaman Regency, Kinali Regency of West Pasaman, Anai Valley Padang Pariaman Regency, Lubuak Basuang Agam Regency and Aia Angek Sijunjung Regency. Wild ginger plants 
contain essential oils from leaves and rhizomes and their roots. Essential oils and volatile compounds from this plant are insecticidal against the Drosophila melanogaster insect which is a vector of blood diseases in banana plants (Nasir et al., 2014).

Research on the effect of wild ginger essential oil on plant pathogenic fungi has not been widely tested, essential oils from leaves can control the pathogen Colletotrichum gloesporioides that causes Antrachnose disease in the red dragon fruit plant Hylocereus polyrhizuz. At the concentration level of $1000 \mathrm{ppm}$ leaf oil can suppress the growth of pathogenic $\mathrm{C}$ gleosporioides $100 \%$ (Nasir \& Nurmansyah, 2016), it is also effective against Phytophthora palmivora fungi (Nasir, 2017).

The main content of wild ginger leaf oil is 2 -decanoic acid $48.04 \%$, nonanoic acid $9.18 \%$, 2-octenal $8.97 \%$, nonanal $2.96 \%$, octanal $1.2 \%$ and 75 other components below $1 \%$ (Nasir \& Nurmansyah, 2016), The main components of rhizomes and roots are 2-Tridecenal 39.81\%, 2decanoic acid 26.3\%, 2 octanal $7.56 \%$, hexadecanoic acid $2.86 \%$, nonanoic acid $3.85 \%$ and 70 other components below 1\% (Nasir, 2016).

Sclerotium rolfsii is a pathogenic fungus that attacks various plants including peanuts, tomatoes, chili, papaya, orchids and soursop. This pathogenic fungus is also known to attack patchouli plants (Sukamto \& Wahyuno, 2013), S rolfsii is a soil borne pathogen such as Botrytis cinerea, Pythium sp, Rhizoctonia solani, Sclerotinia minor dan Verticillium dahlia (Sumartini, 2012; Thiessen \& Woodward, 2012)

The yield decrease caused by $S$. rolfsii fungus attack on peanut plants can reach 44.51 percent (Buhaira \& Asniwita, 2009). Each component has not been tested, therefore further research is recommended. Antifungal essential oil chemical components that are able to penetrate the fungal cell walls, thereby causing interference with the metabolic processes in the cell so that it interferes with cell growth, at certain concentrations will result in the death of the fungal cells.

Control of this pathogen can be done with leaf oil fungicide and cinnamon stick (Cinnamomum burmanii) with a concentration level of $500 \mathrm{ppm}$ able to suppress the growth of the colony 100\% (Nurmansyah, 2014) and Piper aduncum oil at a concentration level of $500 \mathrm{ppm}$ able to control the pathogen $S$ rolfsii reached 92.77\% (Nurmansyah, 2016). Extract of garlic can control the patogen $S$ rolfsii $92.66 \%$ at concentration 5\% (Supriyono, 2011). The cironella and bamboo piper oil botanical fungicides have a good enough ability to suppress the stem rot disease of peanut with an emphasis percentage of 86.38 and $93.21 \%$ at interval application one time a week ( Idris et al, 2020).

Based on the description above, then the use of wild ginger pesticides to control plant diseases has enough potential, considering that these plants are wild plants and will be more beneficial if they can be developed as plants that have economic value for controlling pests and 
plant diseases. This study aims to look at the effectiveness of leaf oil fungicides, wild ginger rhizomes (Ellettariopsis slahmong CK Lim) and their fraction of Sclerotium rolfsii fungi that cause root rot disease in the peanut an in vitro.

\section{Methods}

The study was conducted from April to December 2018 in the pest and disease laboratory of the Laing Solok Experiment Garden in West Sumatra.

\subsection{Distillation and fractionation}

Wild ginger oil is obtained by distillation of leaves and rhizomes, which are withered for 4 days for the leaves first, while the rhizomes are dried for about 10 days, the ingredients are chopped before being distilled first. Distillation is carried out using a kettle protip Balittro system of steam, the results of the distillation of leaf oil and rhizomes are mixed and fractionated at the Faculty of Agriculture of Kogoshima University Japan (by means of multilevel distillation), seven fractions are obtained and there are quite a large volume number of four fractions namely the A1, B2, C3 and D4 fractions. Leaves, rhizomes and fractions obtained in the identification of chemical components contained using GC-MS in Andalas University Laboratory Padang.

\subsection{Pathogen isolation}

Sclerotium rolfsii isolates were obtained by isolating from peanut plants that were attacked by stem rot rot in the Payo area of Tanjung Harapan Solok sub-district. Isolates were identified and propagated Potato Dextrosa Agar (PDA) media as the source of the inoculum to be tested, isolates were used 5 days old in PDA media.

\subsection{Antifungal power testing}

\subsubsection{Pression of Sclerotium rolfsii colony diameter}

Tests are carried out by mixing until homogeneous the treatment material into a sterile PDA medium, according to the treatment and concentration tested before freezing $\left(45^{\circ} \mathrm{C}\right)$, then poured into petridish and allow to harden, after hardening the inoculation of fungi, fungal mat from the Sclerotium rolfsii fungus is cut with a sterile corkbore diameter of $6 \mathrm{~mm}$, placed in the middle of the treated medium, then incubated in an incubator of $28^{\circ} \mathrm{C}$ for 4 days. The experiment was arranged in the form of a Completely Randomized Design (CRD) in factorial each of 4 replications, the treatments were: Leaf oil and roots of wild Ginger and fractions A1, B2, C3 and D4 as factors I, concentration levels (0, 100, 250 and $500 \mathrm{ppm})$ as factor II.

\subsubsection{Emphasis of colony biomass}

Tests using Patato Dextrose Broth (PDB) liquid medium, as much as $25 \mathrm{ml}$ of the medium are input into each test tube, then sterilized in an autoclave, after sterile is cooled and then put the treatment material to be tested according to concentration, then do inoculation of fungi test, the fungal mat of the Sclerotium rolfsii mushroom was cut with a sterile corkbore of $6 \mathrm{~mm}$ in diameter, 
and inserted into the treated medium, then incubated in an incubator of $28^{\circ} \mathrm{C}$ for 4 days. The experiments were arranged in the form of a Completely Randomized Design (CRD) in factorial each of 4 replications. The treatments were: Leaf oil and wild ginger root fractions A1, B2, C3 and D4 as factors I, concentration levels $(0,100,250$ and $500 \mathrm{ppm})$ as factor II. Furthermore, the growth of fungal colonies was taken and dried in an oven at $80^{\circ} \mathrm{C}$ for 48 hours, then the biomass was weighed. Inhibition or suppression of colony diameter and biomass growth, calculated by the formula (Pandey et al, 1982 in (Noveriza \& Miftakhurohmah, 2010)

$$
x=\frac{b-a}{b} \times 100 \%
$$

$\mathrm{X}=$ Percentage inhibition growth of diameter/biomass colony

$\mathrm{a}=$ Diameter/biomass growth of treatment

$\mathrm{b}=$ Diameter/biomass growth of control (untreated)

\section{Results and Discussion}

The results showed that leaf oil, rhizome and fraction of wild ginger (Elettariopsis slahmong) are antifungal and can inhibit the growth of the fungus Sclerotium rolfsii which causes rot disease of the stem base of the peanut plant. A1 and B2 fractions showed better antifungal effectiveness compared to essential oils of leaves and rhizomes and fractions of C2 and D4 (Table 1)

Table 1. Effect of leaf, rhyzom and fraction of essential oils of E. slahmong and concentration level against Sclerotium rolfsii colony diameter growth (4 DAI)

\begin{tabular}{lccl}
\multicolumn{1}{c}{ Treatments } & Colony diametre (mm) & Inhibition (\%) \\
\hline Botanical pesticide & & & \\
Leaf oils & 44.18 & 47.31 & $\mathrm{c}$ \\
Rhizome oils & 44.69 & 46.71 & $\mathrm{~cd}$ \\
Fraction A1 & 42.37 & 49.47 & $\mathrm{a}$ \\
Fraction B2 & 43.19 & 48.50 & $\mathrm{~b}$ \\
Fraction C3 & 54.75 & 34.70 & $\mathrm{e}$ \\
Fraction D4 & 45.00 & 46.34 & $\mathrm{~d}$ \\
\hline Concentration level & & & \\
0 ppm (Control +) & 81.75 & 2.69 & $\mathrm{~d}$ \\
100 ppm & 53.71 & 36.92 & $\mathrm{c}$ \\
250 ppm & 32.08 & 61.69 & $\mathrm{~b}$ \\
500 ppm & 15.25 & 81.74 & $\mathrm{a}$ \\
Control (without treatments) & 83.75 & 0.00 & - \\
\hline CV (\%) & - & 1.98 \\
\hline Note. The numbers followed by the same letter are not significantly different according to \\
DMRT. Test at 5\% level. DAI (days after inoculations). Control+ (Solvents and emulsifiers)
\end{tabular}

From Table 1 it can be seen that the leaf essential oil with rhizome is not statistically significantly different, but the leaf oil rate is more fungicidal than rhizome oil, so the fraction of D4 with rhizome oil is also not statistically significantly different.

The higher of concentration level the smaller the diameter of the test mushroom colony. At a concentration of $500 \mathrm{ppm}$ the suppression of $S$. rolfsii fungi colony diameter growth reached $81.74 \%$. 
The interaction of essential oils of leaves, rhizomes and fraction of wild ginger with a concentration level showed that the higher the concentration level the higher the inhibitory effect on the diameter growth of the test fungi colonies (Table 2).

Table 2. Interactions of leaf oil, rhizome and E. slahmong fraction with levels concentration on growth of Sclerotium rolfsii colony diameter (4 days after inoculation)

\begin{tabular}{|c|c|c|c|}
\hline \multirow{2}{*}{$\begin{array}{l}\text { Treatments } \\
\text { Leaf oil s(Md) }\end{array}$} & \multirow{2}{*}{ Colony diameter (mm) } & \multicolumn{2}{|c|}{ Inhibition growth (\%) } \\
\hline & & & \\
\hline $0 \mathrm{ppm}$ & 81.75 & 2.39 & $\mathrm{~m}$ \\
\hline 100 ppm & 52.50 & 37.31 & $\mathrm{j}$ \\
\hline $250 \mathrm{ppm}$ & 29.50 & 64.77 & fg \\
\hline $500 \mathrm{ppm}$ & 13.00 & 84.78 & $\mathrm{~b}$ \\
\hline \multicolumn{4}{|l|}{ Rhizome oils(Mr) } \\
\hline $0 \mathrm{ppm}$ & 81.75 & 2.39 & $\mathrm{~m}$ \\
\hline 100 ppm & 53.50 & 36.11 & $\mathrm{jk}$ \\
\hline $250 \mathrm{ppm}$ & 30.00 & 64.18 & $\mathrm{~g}$ \\
\hline 500 ppm & 13.50 & 83.88 & $\mathrm{bc}$ \\
\hline \multicolumn{4}{|l|}{ Fraction A1 } \\
\hline 0 ppm & 81.75 & 2.39 & $\mathrm{~m}$ \\
\hline 100 ppm & 48.75 & 41.78 & $\mathrm{i}$ \\
\hline $250 \mathrm{ppm}$ & 27.50 & 67.16 & de \\
\hline 500 ppm & 11.50 & 86.26 & $\mathrm{a}$ \\
\hline \multicolumn{4}{|l|}{ Fraction B2 } \\
\hline 0 ppm & 81.75 & 2.39 & $\mathrm{~m}$ \\
\hline 100 ppm & 50.00 & 40.59 & $\mathrm{i}$ \\
\hline $250 \mathrm{ppm}$ & 28.50 & 65.97 & ef \\
\hline $500 \mathrm{ppm}$ & 12.50 & 84.78 & $\mathrm{~b}$ \\
\hline \multicolumn{4}{|l|}{ Fraction C3 } \\
\hline 0 ppm & 81.75 & 2.39 & $\mathrm{~m}$ \\
\hline $100 \mathrm{ppm}$ & 63.50 & 24.18 & 1 \\
\hline $250 \mathrm{ppm}$ & 47.25 & 43.58 & $\mathrm{~h}$ \\
\hline 500 ppm & 26.50 & 68.35 & $\mathrm{~d}$ \\
\hline \multicolumn{4}{|l|}{ Fraction D4 } \\
\hline 0 ppm & 81.75 & 2.39 & $\mathrm{~m}$ \\
\hline 100 ppm & 54.00 & 35.52 & $\mathrm{k}$ \\
\hline $250 \mathrm{ppm}$ & 29.75 & 64.48 & fg \\
\hline $500 \mathrm{ppm}$ & 14.50 & 82.68 & c \\
\hline
\end{tabular}

Note. The numbers followed by the same letter are not significantly different according to DMRT. Test at 5\% level.

From Table 2, it can be seen that the concentration level of $100 \mathrm{ppm}$ of wild ginger essential oil and the fraction has shown an emphasis on the growth of $S$. rolfsii mushroom colony diameter with growth suppression ranging from $24.18-41.78 \%$ and at a concentration level of 500 ppm A1 fraction has been able suppress the growth of test fungi colonies by $86.26 \%$, while in leaf essential oil the growth of new colonies increased to $84.78 \%$ at the same concentration level.

Test results on Sclerotium rolfsii fungi biomass on Patato Dextrosa Broth media showed that fungal biomass growth suppression was quite effective, colony biomass in the treatment of A1 fraction showed the highest suppression of colony biomass growth compared to B2, leaf oil, 
rhizome, and D4 fractions, C3 fraction showed effective suppression of biomass colonies in A1 treatment. The Suppression of the lowest colony biomass growth (Table 3).

Table 3. Effects of essential oils of leaves, rhizomes and E. slahmong fraction as well as levels concentration of Sclerotium rolfsii colony biomass growth (4 DAI)

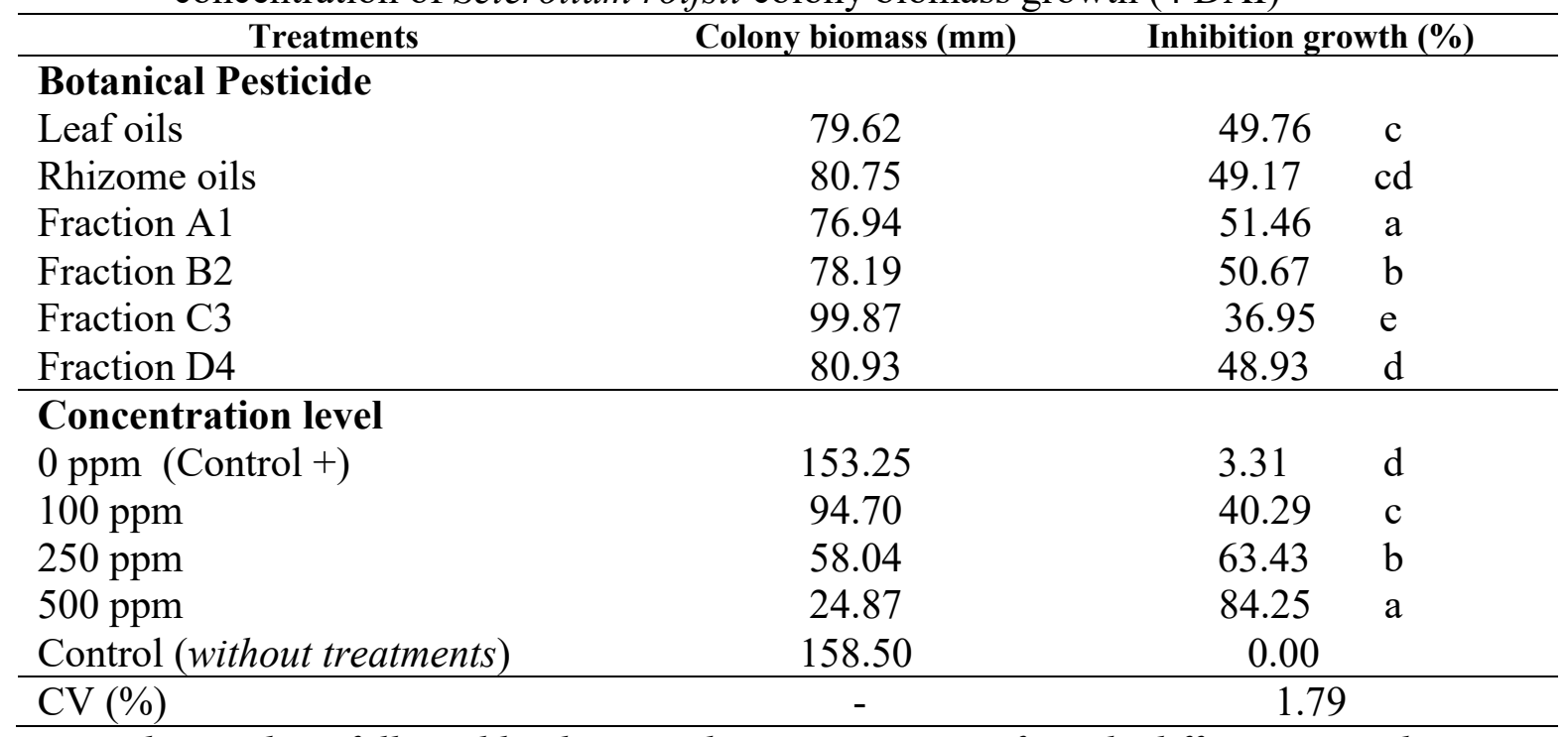

Note. The numbers followed by the same letter are not significantly different according to DMRT. Test at 5\% level. CV (coefficient variation). Control+ (Solvents and emulsifiers)

The interaction of essential oils of leaves, rhizomes and wild ginger fraction with the concentration level, showed that the higher the concentration level, the higher the inhibitory power of the biomass colony of the test fungus. At the concentration level of 500 ppm A1 and B2 fractions, no significant difference was seen in suppressing the growth of S.rolfsii fungi colony biomass, with growth suppression reaching $88.10 \%$ and $87.22 \%$, but significantly different from leaf oil, rhizomes and other fractions . Leaf oil, rhizome and D4 fraction also did not show a statistical difference, but significantly different from the C3 fraction with the lowest growth suppression of $72.55 \%$ at the same concentration level (Table 4 ).

From Table 1-4 shows that the fraction A1, A2, leaf oil and wild ginger rhizome have a high antifungal power against the $S$ rolfsii fungi significantly different from the $\mathrm{C} 3$ fraction and the D4 fraction. The main components contained in wild ginger leaf oil are 2-Decanoic acid (48.04\%), nonanoic acid (9.18\%), 2-octenal (8.97\%), hexanoic acid (2.46\%), 6-tetradecene (2.35\%), nonanal (2.06), ascobic acid (1.66\%), heptanoic acid (1.61\%) and octanal (1.20\%). In the main content of rhizome oil are 2-Tridecenal (39.81\%), 2-decanoic acid (26.39\%), 2-octenal (7.56\%), hexadecanoic acid (2.86\%), nonanoic acid (3, 85), 2-deconyl acetate (2.31\%), Eucalyptol (2.13\%). In the A1 component, the main components are 2-Decanoic acid (27.24\%), 2-octenal (17.01\%), decenal (12.40\%) and nonanoic acid (1.37\%). The main content of B2 fraction was Decanal (38.31\%), octanal (8.42\%), 6-tetradecene (3.24\%), 2-octenoic acid 2.03\%), and octenal (1.56\%). C3 fraction containing 2-Tridecenal (26.57\%), decanal (25.65\%), 2-octenal (7.75\%), 2propenoic acid (5.11\%), 2-decenyl acetate (5) , 44\%), benzaldehyde (3.87\%), and dedecenal 
$(2.35 \%)$ and the D4 fraction of the uatam content was 2-Tridecenal (19.41\%), 2-dimethyl (3cloropropyl) sililoxymethyltetra (16.99\%), 2-octenal (16.08\%), 1-ethyl-1- (undec-10-enyl) oxy1-silacyclopenta (15.99\%), decanal (2.87\%), octanal $(2.84 \%)$, 6-tridecene $2.79 \%$ (Nasir \& Nurmansyah, 2016; Nasir, 2016).. Each component has not been tested, therefore further research is recommended. Antifungal essential oil chemical components that are able to penetrate the fungal cell walls, thereby causing interference with the metabolic processes in the cell so that it interferes with cell growth, at certain concentrations will result in the death of the fungal cells.

Table 4. Interactions of leaf oil, rhizome and E. slahmong fraction with concentration levels on growth of Sclerotium rolfsii colony biomass (4 days after inoculation)

\begin{tabular}{|c|c|c|c|}
\hline \multirow{2}{*}{$\begin{array}{l}\text { Treatments } \\
\text { Leaf oils (Md) }\end{array}$} & \multirow[t]{2}{*}{ Colony biomass (mm) } & \multicolumn{2}{|c|}{ Inhibition growth (\%) } \\
\hline & & & \\
\hline 0 ppm & 153.25 & 3.31 & 1 \\
\hline $100 \mathrm{ppm}$ & 90.00 & 43.21 & $\mathrm{i}$ \\
\hline $250 \mathrm{ppm}$ & 53.50 & 66.24 & $\mathrm{f}$ \\
\hline 500 ppm & 21.75 & 86.28 & bc \\
\hline \multicolumn{4}{|l|}{ Rhizome oils (Mt) } \\
\hline 0 ppm & 153.25 & 0.31 & 1 \\
\hline $100 \mathrm{ppm}$ & 93.00 & 41.63 & $\mathrm{j}$ \\
\hline $250 \mathrm{ppm}$ & 54.25 & 65.93 & $\mathrm{f}$ \\
\hline $500 \mathrm{ppm}$ & 22.50 & 85.81 & $\mathrm{c}$ \\
\hline \multicolumn{4}{|l|}{ Fraction A1 } \\
\hline $0 \mathrm{ppm}$ & 153.25 & 3.31 & 1 \\
\hline $100 \mathrm{ppm}$ & 86.50 & 45.42 & g \\
\hline $250 \mathrm{ppm}$ & 49.00 & 69.08 & $\mathrm{e}$ \\
\hline $500 \mathrm{ppm}$ & 19.00 & 88.01 & $\mathrm{a}$ \\
\hline \multicolumn{4}{|l|}{ Fraction B2 } \\
\hline $0 \mathrm{ppm}$ & 153.25 & 3,31 & 1 \\
\hline 100 ppm & 88.75 & 44.00 & hi \\
\hline $250 \mathrm{ppm}$ & 50.50 & 68.13 & $\mathrm{e}$ \\
\hline $500 \mathrm{ppm}$ & 20.25 & 87.22 & $a b$ \\
\hline \multicolumn{4}{|l|}{ Fraction $\mathrm{C} 3$} \\
\hline 0 ppm & 153.25 & 3.31 & 1 \\
\hline $100 \mathrm{ppm}$ & 116.25 & 26.65 & $\mathrm{k}$ \\
\hline $250 \mathrm{ppm}$ & 87.00 & 45.27 & gh \\
\hline $500 \mathrm{ppm}$ & 43.00 & 72.55 & $\mathrm{~d}$ \\
\hline \multicolumn{4}{|l|}{ Fraction D4 } \\
\hline 0 ppm & 153.25 & 3.31 & 1 \\
\hline $100 \mathrm{ppm}$ & 93.75 & 40.85 & $\mathrm{j}$ \\
\hline $250 \mathrm{ppm}$ & 54.00 & 65.93 & $\mathrm{f}$ \\
\hline $500 \mathrm{ppm}$ & 22.75 & 85.65 & $\mathrm{c}$ \\
\hline
\end{tabular}

Note. The numbers followed by the same letter are not significantly different according to DMRT. Test at $5 \%$ level.

From the above results it is clear that decanoic acid is more fungicidal than decanal, (Kumar et al, 2011), reporting that decanoic acid (capric acid) and its esters have been used in medical science and are the best antifungal. The decanal and nonanal are antifungal components that can inhibit the growth of sclerotia of Sclerotinia sclerotiorum that causes stem rot disease 
from the canola and stem rot from the sunflower. Decanoic acid and nonanoic acid at a concentration level of $100 \mathrm{ppm}$ have been able to kill spores from the fungus basidiomycetes that cause brown root disease, pentanoic acid and hexanoic acid are effective against test fungi at a concentration level of 1000 ppm (Schmidt, 1984 in Clausen et al, 2010). Essential oils from wild Ginger leaves can control the pathogen Colletotrichum gloesporioides that causes Antrachnose disease in the red dragon fruit plant Hylocereus polyrhizuz. At the concentration level of $1000 \mathrm{ppm}$ leaf oil can suppress the growth of pathogenic C. gleosporioides fungal colonies $100 \%$ (Nasir \& Nurmansyah, 2016).

According to Lim in (Picheansoonth \& Yupparach, 2007), stated that the results of the Elletaropsis spp oil analysis of the components inside are almost the same as slight differences such as E. elan, the main components are monoterpenes, geraniol $71.6 \%$, comphane and phelandrena. E. smithiae, is the main component of monoterpenes, geraniol $38.10 \%$, neral 29.10\%, comphane and fancylacetate. E. triloba main components are 16,16\% citral, limonane, phellandrena and terpene acetate. The active compounds contained in E. slahmong oil according to CK Lim are terpenoid components, (E)-2-octenal (46,3\%) and (E)-2- decenal 36,8\% rhizomes and roots with the main content (E) -2-decenal 79.4\% (Wong et al, 2006).

Botanical fungicides that have been tested and are effective against $S$. rolfsii fungi are essential oils from Casia vera (Cinnamomum burmanii) leaves and twigs with a concentration level of 500 ppm which can suppress the growth of S. rolfsii colony 100\% (Nurmansyah, 2014) and essential oils from several wild sirih such as sirih hantu, sirih cambai, sirih kaduak and sirih are quite effective in suppressing the growth of this fungus (Nurmansyah, 2012). Bamboo piper essential oil (Piper aduncum) at a concentration level of $500 \mathrm{ppm}$ is able to control the pathogen S rolfsii reaching $92.77 \%$ (Nurmansyah, 2016). This wild ginger fungicide has the bioprospek to be developed because the results are not significantly different from the bamboo piper and cinnamon fungicides.

\section{Conclusions}

The results of the study concluded that leaf oil and rhizome of wild ginger Elettariopsis slahmomong and their fractions have the potential to be used as botanical fungicides. The A1 fraction has the best antifungal effectiveness compared to leaf oil, rhizome and other fractions, leaf oil and rhizome oil are not statistically significantly different, but in terms of leaf oil is better than rhizome oil. The best concentration level in this study was $500 \mathrm{ppm}$ with the highest emphasis on diameter and biomass growth of $81.74 \%$ and $84.25 \%$.

\section{References}

Buhaira \& Asniwita. (2009). Studi pengaruh aplikasi berbagai kosentrasi Sclerotium Rolfsii terhadap kehilangan hasil pada kacang tanah. Jurnal Agronomi, 13(2), 1-4.

Clausen, C. A., Coleman, R. D., \& Yang, V. W. (2010). Fatty Acid-Based Formulations for Wood 
Protection against Mold and Sapstain. Forest Products Journal, 60(3), 301-304.

Idris, Nurmansyah, Helfi Gustia, A. I. Ramadhan. (2020). The Potential and Effectiveness of Three Botanical Fungicides to Control Stem Rot Disease in Peanuts. Technogy Report of Kannsai Univercity, 62(4), 1745-1752.

Kumar, A., Jain, S., Industries, S. P., \& Kumar, P. (2011). Synthesis, antimicrobial evaluation, QSAR and in Silico ADMET studies of decanoic acid derivatives. Acta Poloniae Pharmaceutica ñ Drug Research, 68(2), 191-204.

Magdaulih, E., \& Nasir, N. (2014). Antifungal Activity of Essential Oil of Cymbopogon nardus L. and Elettariopsis slahmong Lim. against Colletotrichum sp. on Red Dragon Fruit (Hylocereus polyrhizus). J. Bio. UA, 3(2), 97-102.

Nasir, Dharma. A, Efdi. M, \& Yuhendra, E. F. (2014). Natural product of wild Zingiberaceae Elettariopsis slahmong biopesticide to control the vector of banana blood disease bacterium in West Sumatera. Research of Pharmaceutical Biological and Chemical Science, 5(5), $1250-1256$.

Nasir. (2017). Essential oils from Elettariopsis slahmong C. K. Lim and Cinnamomum burmanii [Nees \& T. Nees] Bl. inhibit the colony growth of Phythopthora palmivora of cocoa. Scholars Research Library Der Pharmacia Lettre, 9(4), 95-107.

Nasir \& Nurmansyah. (2016). Leaf Essential Oil of Wild Zingiberaceae Elettariopsis slahmong CK Lim to Control Antrachnose Disease in Red Dragon Fruit Hylocereus polyrhizus. Research Journal of Pharmaceutical, Biological and Chemical Sciences, 7(5), 2463-2471.

Nasir, N. (2016). Rhizome essential oil and fractions of Elettariopsis slahmong CK. Lim against Colletotricum gloesporioides in red dragon fruit Hylocereus polyrhizus. Research Journal of Pharmaceutical, Biological and Chemical Sciences, 7(2164), 2164-2171.

Noveriza, R., \& Miftakhurohmah. (2010). Efektivitas Ekstrak Metanol Daun Salam ( Eugenia polyantha ) dan Daun Jeruk Purut ( Cytrus histrix ) sebagai Antijamur pada Pertumbuhan Fusarium oxysporum. Jurnal Littri, 16(1), 6-11.

Nurmansyah. (2012). Minyak Atsiri Piper aduncum sebagai Bahan Baku Pestisida Nabati untuk Pengendalian Jamur Penyakit Tanaman. Bunga Rampai Inovasi Tanaman Atsiri Indonesia, $178-186$.

Nurmansyah. (2014). Kajian Potensi Minyak Atsiri Kayu manis Cinnamomum burmanii sebagai Bahan Baku Pestisida Nabati untuk Pengendalian Jamur Patogen Tanaman. Prosiding Seminar dan Kongres XXII Pershimpunan Fitopatologi Indonesia, 385.

Nurmansyah. (2016). Pengaruh Minyak Nabati Piper Aduncum Terhadap Jamur Sclerotium Rolfsii Menurut Ketinggian Lokasi Tanam Dan Waktu Penyulingan. Bul. Littro, 27(2), 147-154. http://dx.doi.org/10.21082/bullitro.v27n.2016.147-154

Picheansoonthon, C., \& Yupparach, P. (2007). Notes on The Genus Elettrariopsis Baker (Zingiberaceae) in Thailand. Journal of Thai Tarditional \& Alternative Medicine, 5(3), 2940.

Picheansoonthon, C., \& Yupparach, P. (2010). Further Study on the Elettariopsis Baker (Zingiberaceae) in Thailand - a New Species and a New Record. Taiwania, 55(4), 335-341.

Sukamto \& Wahyuno, D. (2013). Identifikasi dan karakterisasi Sclerotium rolfsii Sacc . penyebab penyakit busuk batang nilam (Pogostemon cablin Benth). Bul. Littro, 24(1), 35-41.

Sumartini. (2012). Penyakit Tular Tanah (Sclerotium rolfsii dan Rhizoctonia solani) pada Tanaman Kacang kacangan dan Umbi umbian serta cara Pengendaliannya. Jurnal Litbang Pertanian, 31(1), 27-34.

Supriyono. (2011). Potensi Ekstrak Bawang Putih sebagai Fungisida Nabati terhadap Jamur Sclerotium rolfsii Sacc. In Prosiding Konser Karya Ilmiah (hal. 17-22).

Thiessen, L. D., \& Woodward, J. E. (2012). Diseases of Peanut Caused by Soilborne Pathogens in the Southwestern Diseases of Peanut Caused by Soilborne Pathogens in the Southwestern United States. International Scholarly Research Network ISRN Agronomy, 2012, 9. https://doi.org/10.5402/2012/517905

Wong, K. C., Sivasothy, Y., \& Boey, P. L. (2006). Essential oils of Elettariopsis slahmong CK 
Lim. Journal of Essential Oil Research, 18(2), 203-205.

https://doi.org/10.1080/10412905.2006.9699066 